\title{
CHANGES IN HABITAT CONDITIONS OF INVADED FOREST COMMUNITIES IN PODUNAJSKÁ NÍŽINA AND THE IMPACT OF NON-NATIVE SPECIES ON BIODIVERSITY (SW SLOVAKIA)
}

\author{
MONIKA LUKOVIČOVÁ ${ }^{1}$, ZUZANA BALANAC $^{1}$, STANISLAV DAVID $\otimes^{2}$ \\ ${ }^{1}$ Department of Ecology and Environmental Sciences, Faculty of Natural Sciences, Constantine the Philosopher University in Nitra, Tr. A. Hlinku 1, 94974 \\ Nitra, Slovak Republic; e-mail: monika.lukovicova@ukf.sk, zuzana.balanac@ukf.sk \\ ${ }^{2}$ Institute of Landscape Ecology, Slovak Academy of Sciences, branch Nitra, Akademická 2, 94974 Nitra, Slovak Republic; e-mail: stanislav.david@savba.sk
}

\section{Corresponding author}

Received: 4 March 2021 / Accepted: 19 July 2021

\begin{abstract}
Lukovičová M., Balanac Z., David S.: Changes in habitat conditions of invaded forest communities in Podunajská nízina and the impact of non-native species on biodiversity (SW Slovakia). Ekológia (Bratislava), Vol. 40, No. 4, p. 364-378, 2021.

With the phytocenological research of riparian mixed forests and pannonic woods in the Podunajská nízina in 2018 and 2019, we obtained 113 phytocenological relevés of invaded and non-invaded stands. Using the Modified Permutation Test, we derived modified Ellenberg indication values (EIVs) in order to determine statistically significant differences and correlation relationships between diversity indices and EIVs. We recorded 15 invasive species in the stands, for example, Ailanthus altissima, Ambrosia artemisiifolia, Asclepias syriaca, Aster lanceolatus, Helianthus tuberosus, Impatiens parviflora, Negundo aceroides, Solidago canadensis, S. gigantea and Robinia pseudoacacia. We also confirmed the occurrence of species important for conservation: Epipactis helleborine agg., E. voethii, Cephalanthera longifolia, Clematis integrifolia and the like. We tested the statistical significance of EIVs as explanatory variables by redundancy analysis and Monte Carlo permutation test (stepwise selection, number of permutations $499, p<0.05$ ). In addition to the EIV continentality, the contribution of light, moisture, nutrients, soil reaction and temperature was higher than random. The model explains $20.21 \%$ of the variability pursuant to the coefficient of determination $\left(R^{2}\right)$, with its adjusted (more accurate) variant $\left(R_{\text {add }}^{2}\right)$ capturing $15.70 \%$ of the variability of the model. Using the Kruskal-Wallis test, we confirmed the statistically significant differences $\left(p^{*}\right)$ in mean values between count of species, Shannon-Wiener index, Simpson dominance index and taxonomic diversity of invaded and non-invaded vegetation. For EIVs, we found significant differences in the mean values for moisture and soil reaction factors. In our model, count of species, Shannon-Wiener index, Simpson dominance index and taxonomic diversity index were positively correlated with invaded stands. Non-invaded stands showed statistically significant negative correlation with the EIVs moisture, soil reaction and nutrients. Biotic indices are appropriate and sensitive metrics for assessing the rate of community invasion. Lowland riparian forests are dynamic ecosystems through the structure of their stands and the dynamics of the nutrient and energy cycle of the river landscape. After disturbance (fire, wind, logging), the high degree of invasibility makes them vulnerable to the infiltration and spread of non-native species, which is a problem, especially in protected areas.
\end{abstract}

Key words: riparian mixed forests, pannonic woods, alien species, Ellenberg's indicator values, biodiversity indices, habitats of European interest.

\section{Introduction}

The occurrence of invasive species contributes significantly to the destruction of stability and functions of ecosystems and a reduction of biodiversity and related ecosystem services at the global and local levels (Chytrý et al., 2005; Vilà, Ibáñez, 2011). The European Union, as a party to the Convention on Biological Diversity (CBD), is committed to preventing the introduction of non-native species and eliminating those that pose the greatest threat (EC, 2020). At the same time, invasive species are also the subject of research as a threat to ecological stability and economic prosperity at the regional (e.g. Hrivnák et al., 2019; Štajerová et al., 2017) and global (Chytrý et al., 2009; Bartz, Kowarik, 2019) levels. According to the inventory of invasive species of Europe
- DAISIE (Daisie, 2019), 5,789 plant species are registered and up to 2,843 of them are non-native. The list of invasive species of the EU (EU Regulation 1143/2014) originally contained 14 species of invasive plants and the update in 2017 increased the number to 23 invasive plant taxa. The latest version of the list from 2019 contains 36 invasive alien species of plants, some of them with the occurrence in Slovakia for example Ailanthus altissima, Asclepias syriaca, Elodea nuttallii, Heracleum mantegazzianum and Impatiens glandulifera. For Slovakia, Medvecká et al. (2012) specify 3,337 species and subspecies (including hybrids) native taxa and Slovak alien flora which consist of 282 archaeophytes and 634 neophytes (including subspecies and hybrids); in total, there are 4,253 taxa in the Slovak flora and 916 alien taxa, making up $21.5 \%$ of the total flora. The National List of the Slo- 
vak Republic (No. 24/2003 Coll.) contains 13 invasive taxa at the species level (Ambrosia artemisiifolia, Asclepias syriaca, Fallopia spp. [syn. Reynoutria], Heracleum mantegazzianum, Impatiens glandulifera, Solidago canadensis, S. gigantea and four species of woody plants Ailanthus altissima, Amorpha fruticosa, Lycium barbarum, Negundo aceroides) and the provisions of Act no. $150 / 2019$ Coll. on the prevention and management of the introduction and spread of invasive alien species apply to them. Monitoring represents an important part of the management of invasive plant species in Slovakia. At the national level, it includes the Complex Information and Monitoring System (KIMS), which is one of the available products for monitoring EU species and habitats under the Operational Program Environmental Quality. It is a source of information in the development of regional and national lists and strategies.

In the past, mixed ash-alder alluvial and riparian mixed woodland forest covered large parts of the territory of the large lowlands of Slovakia. Since the Neolithic, these have been intensively transformed into arable land, pastures and meadows. As a result of changing natural conditions, agricultural and forestry activities, floodplain forest formations have almost disappeared. The woody composition of the floodplain forests changed, especially by conversion to plantations of poplar trees (populetum), which were formed by a cross between European and North American poplars Populus nigra $\times$ Populus deltoides (=Populus $x$ euroamericana $c v$., in the Slovak botanical nomenclature Populus $x$ canadensis) and their cultivars, for example, Robusta, I-214, Pannonia (Bartko, 2018). If the hydrological and geomorphological characteristics of the river landscape are at least partially preserved, according to the concept of the river continuum (Vannote et al., 1980), riparian forests are highly dynamic ecosystems (floods, biomass accumulation, species migration). However, this exceptionality is conditioned by the preservation of fluvial landscaping processes (Hutárová, 2011). Interventions into the natural species composition of phytocenoses, fragmentation of riparian forest stands and changes in habitat conditions have created suitable opportunities for the infiltration and spread of non-native (invasive) plant species (Fehér, 2007, 2018; Pauková, 2013; Májeková, Vykoukalová, 2010; Uherčíková, 2001). The penetration and spread of invasive species in forest stands is aggressive and is being studied in terms of changes in biodiversity and nutrient, water and carbon cycles as key functions of the forest ecosystem. Liebhold et al. (2017) list 3,749 non-native species in Europe's forest ecosystems. In the management of invasions into forest stands, they focus on the identification of sources and ways of spreading of the non-native (invasive) species. In Slovakia, the study of invaded forest (and riparian) stands has a long tradition. Jarolímek (1993) published one of the first synecological studies of communities with Impatiens glandulifera in riparian forests and riparian stands. In records from the riparian forests of the Podunajská nízina and the Podunajská rovina, $I$. glandulifera was an edifier, creating closed 2-2.5 (3.5)-m-high stands with a coverage of 75-100\%. Urtica dioica, Calystegia sepium, Artemisia vulgaris and Impatiens parviflora were found in the stands with high stability. In addition to the herbaceous layer, non-native species and invasive species are also present in forest stands in the shrub and tree level. An overview of the occurrence of invasive shrubs and trees in 15 regions (geographical areas), including hot spots biodiversity (New Zealand, Australia) was compiled by Richardson and Rejmánek (2011). The authors compiled a list of invasive trees (357 species) and shrubs (265 species), with the highest species richness found for the orders Pinales (38 invasive species), Fabales (123 invasive species) and Rosales (107 invasive species). According to the authors, the spread of non-native species and the degree of invasiveness are also significantly affected by ongoing climate change. Some taxa are given special attention in their secondary area of occurrence or their occurrence in protected areas. An example is the Black locust (Robinia pseudoacacia), also represented in our study area. The original centre of occurrence is the Appalachian Mountains in the eastern parts of the USA, and the introduction to Europe is associated with the chief gardener of Louis XIII named Jahann Robin and dates back to 1600 or 1601 . The years $1630-1638$ are sometimes also mentioned, but these are the years of planting false acacia in the Jardin des Plantes by Vespasian Robin (Vadas, 1914). In Europe, R. pseudoacacia is naturalised in 32 countries, covering an area of approximately 2.3 million ha. In Slovakia, it has been planted in forest stands since about 1780 (Nicolescu et al., 2020). The first large afforestation (290 ha) with black locust happened in 1750 to protect the fortifications of Komárom-Herkály in Hungary (Vítková et al., 2017). However, in forest stands with natural species composition and environmental functions and in protected areas (also in Natura 2000 areas), strict eradication of black locust is necessary using all techniques of manual, mechanical, chemical and biological control (Fehér, Borlea, 2018; Nicolescu et al., 2020; Vítková et al., 2017; Vološčuk, 2002). In terms of factors preventing the spread of non-native species in traditional agricultural landscapes in the hills and foothills of Slovakia, an interesting study comes from Špulerová et al. (2017). Based on the typical elements of land use (dispersal settlement, vineyard, arable land, grasslands and orchards), the authors identified solitary trees, tree lines shrub lines and small woody stands. They reported a high occurence frequency of Tilia platyphyllos, Quercus petraea agg., Carpinus betulus, Fraxinus excelsior, Acer pseudoplatanus, A. campestre, Prunus spinosa agg., Rosa canina agg., Viburnum opulus, Sambucus nigra and Corylus avellana. The authors did not report the occurrence of non-native or invasive species.

The current state of knowledge has confirmed a significant threat to biodiversity at the genetic and species level, including the possibility of inducing synergistic effects of changes in community composition, biotic interactions and ecosystem processes with significant economic damage. This creates the need to manage non-native and invasive species with significant financial costs and commitment of human resources. Therefore, invasive species have become a scientific, economic and political problem. As Bartz and Kowarik (2019) point out, a distinction needs to be made between non-native species which may be beneficial to native species and to ecosystem services and those which are not. On the contrary, invasive species are subject to management measures and the obligation to protect biodiversity under international legislation (EC, 2020). Research into the assessment of the negative impacts of invasive species is important. An effective tool for conservation argumentation and resulting measures includes the measurement of changes (loss) in species richness, community diversity and ecosystem diversity. Appropriate metrics (indices) to measure it are being identified or rediscovered. Invaded ecosystems change, according to the time course of the successive development, the quantitative and structural characteristics (species richness, dominance and cover of 


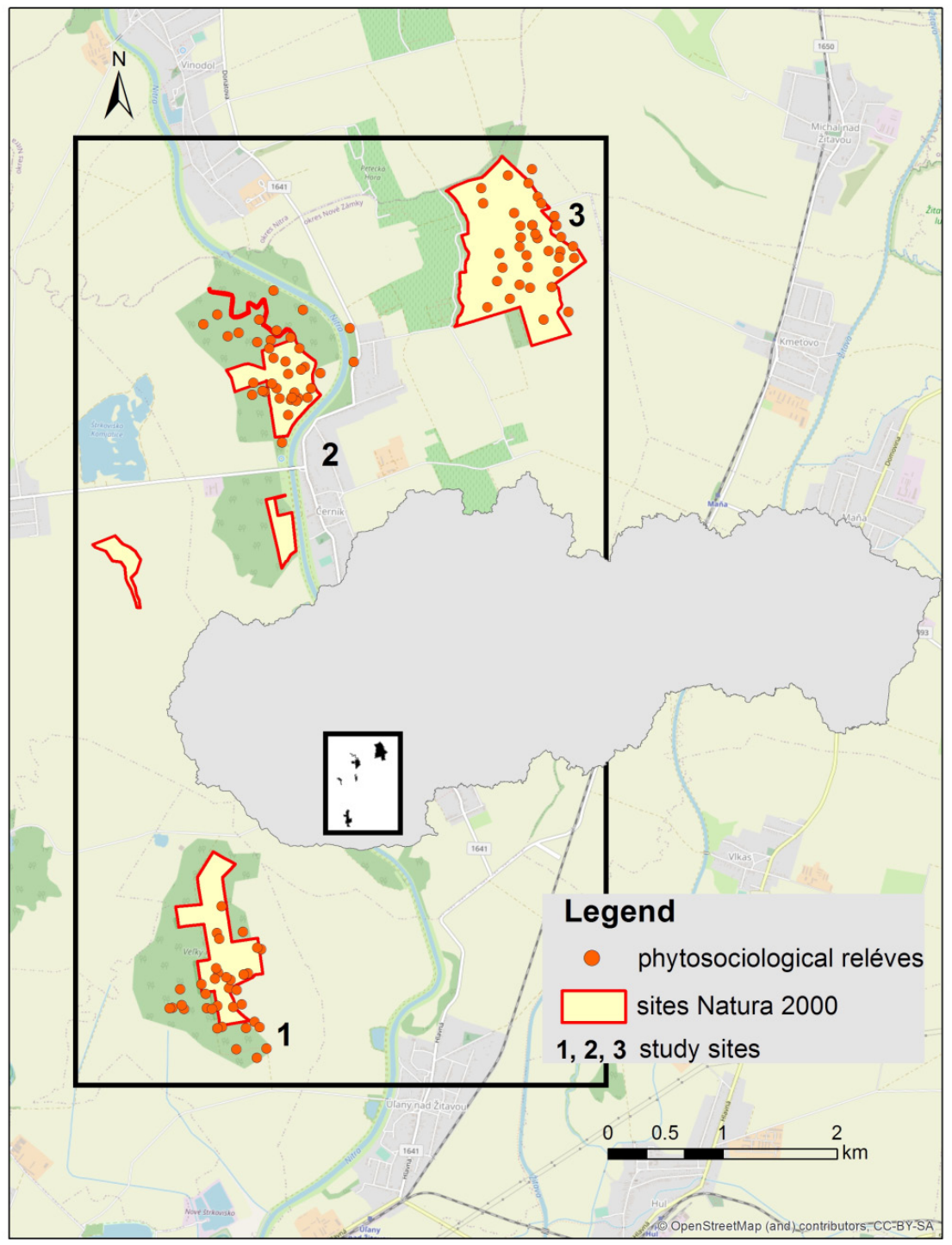

Fig. 1. Location of studied forest stands 1 - Velký les, 2 - Dolný háj, 3 - Horný háj.

species, etc.). Appropriate metrics, based on the value of $p_{i}$ (the proportion of individuals belonging to the $i$ th species in the dataset of interest), include the Shannon-Wiener $\left(\mathrm{H}^{\prime}\right)$ Entropy index (Spellerberg, 2008), Simpson dominance index (1) (Simpson, 1949), equitability index $\left(\mathrm{E}_{\mathrm{H}}\right)$ and evenness index (Sheldon, 1969). Dominance indices, Shanon-Wiener information index and equitability were used to assess changes in regenerated natural rainforest after planting of Pinus ssp., Araucaria angustifolia and Eucalyptus spp. (Kanieski et al., 2018). In Europe, these indices were used by Perzanowska et al. (2019) to assess the threat to Natura 2000 habitats from non-native species in Poland. Among other things, they stated that alluvial forests should be monitored more closely, as non-native species tend to spread very rapidly in these habitats. These metrics were used for the correlation analyses of indices with Ellenbeg indication values (EIVs) by Jastrzębska et al. (2009). Statistically significant results ( $p^{* *}$, $\left.p^{* * *}\right)$ indicated the difficulty of interpreting the results. For pasture communities, the correlation EIV light was $-\mathrm{H}^{\prime}=0.23^{\star *}$, $\mathrm{l}=-0.26^{\star \star}$, for moisture $-\mathrm{H}^{\prime}=0.41^{\star \star \star}, \mathrm{l}=0.45^{\star \star \star}$ and for soil reaction $\mathrm{H}^{\prime}=-0.52^{\star * *}, \mathrm{l}=0.54^{\star * \star}$. Chmuraa and Sierka (2006) used Hill indices $\left(\mathrm{N}_{0}-\right.$ number of species in a sample, $\mathrm{N}_{1}-\mathrm{e}^{\mathrm{H}}$ and $\mathrm{N}_{2}$ - inverse Simpson index), Shannon-Wiener index, Evenness and Alfa and Beta diversity to evaluate species richness and diversity of studied areas with and without the presence of invasive neophyte Impatiens parviflora (Asiatic small balsam). The forest ecosystems of oak-hornbeam, beech forests, mixed coniferous forest and alder forests in Silesian-Kraków Upland were investigated. They, for instance, identified negative correlation of the percentage cover of I. parviflora and species richness in areas in the riparian forest. The invasion of new sites and the persistence of I. parviflora is often the result of occupation of a free habitat niche, the size of the area and the availability of nutrient sources. However, several studies confirm that species richness was more negatively affected by the number of individuals of the invasive species than the size of its area. Of particular importance for Slovakia and Central Europe is the use of the above (and other) in- 


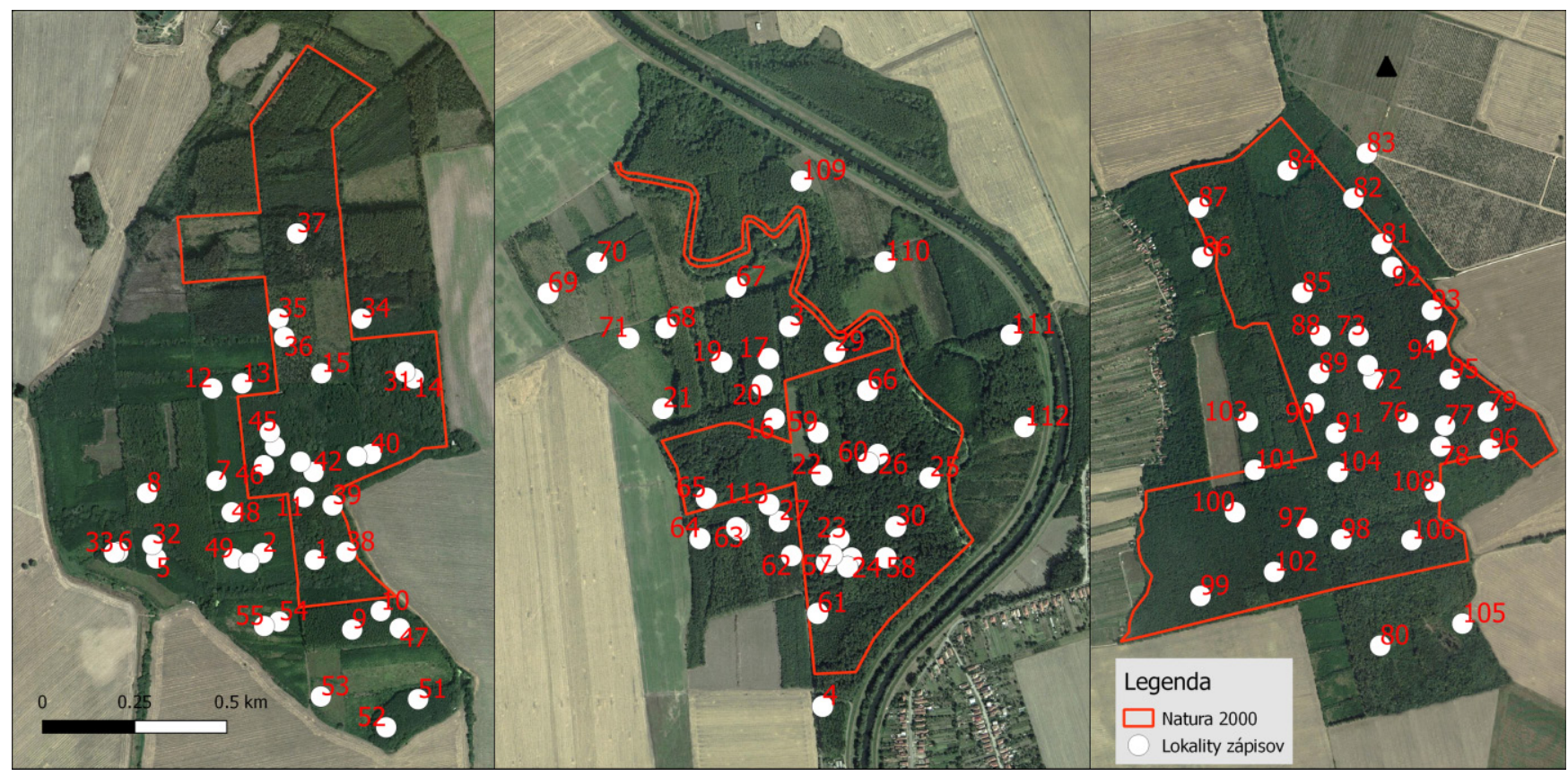

Fig. 2. Localisation of phytocenological relevés in stands 1 - Velký les, 2 - Dolný háj, 3 - Horný háj.

dices for the evaluation of various vegetation properties (Jurko, 1990). Relatively new metrics evaluating biodiversity include the taxonomic diversity index (D) published by Clark and Warwick (1998). Unlike the above metrics, based on the $\left(p_{i}\right)$ index (D), it randomises the 'taxonomic distinctness' of species $i$ and $j$ in the classification system as well as the total number of individuals in the sample.

The aim of this study is to analyse the changes in species richness and diversity of invading and non-invading forest communities of the Podunajská pahorkatina and to determine the relationships between biodiversity and the influencing factors of their habitats.

\section{Material and methods}

\section{Study area}

The research of the invaded vegetation took place in the southern part of western Slovakia, in three separate forest units: Horný háj, Dolný háj and Vel'ký les (Fig. 1). They are bordered by largescale arable and agricultural intensively used land. From the administration point of view, the localities are part of the Nitra selfgoverning region, in the Nové Zámky district, in the Podunajská pahorkatina geomorphological unit and part of two geomorphological subunits (Kočický, Ivanovič, 2011): Nitrianská niva (locality 1 Velký les and locality 2 Dolný háj) and Žitavská pahorkatina (locality 3 Horný háj). The research areas are located in the southern part of the basic river basin Nitra. Localities 1 and 2 are part of the inundation area of the river Nitra, with the long-term average flow $\left(\mathrm{Q}_{\mathrm{a}}\right)$ at the Nové Zámky water meter station (12.30 rkm, $108.7 \mathrm{~m}$ above sea level) for the period from 1961 to 2000 being at $Q_{a}=19.920 \mathrm{~m}^{3} \mathrm{~s}^{-1}$. For floodplain vegetation, it is important that after water management modifications of river inundation and the Nitra riverbed, there is no potentially significant flood risk (SHMÚ, 2019), and thus the possibility of floods. The area has a deficit of precipitation with the climatic values of humidification pointing to insufficient average precipitation (Tomlain, 2002). In terms of reconstructed natural vegetation (Berta, 1986), the stands at localities 1 and 2 belonged to the lowland riparian forests (Ulmenion sub-alliance), where we classify moisture-loving and partly mesohydrophilic forests. Ashelm and oak-elm forest communities are associated with relatively drier valley floodplains of lowlands and hills (Maglocký, 2002). Locality 3 is part of the southern outcrop of the Žitavská pahorkatina, which were overgrown with Pannonian oak-hornbeam (Querco robori-Carpinenion betuli) and Turkey oak forests (Quercetum petraeae-cerris s. 1.) on the Neogene and loess sediments (Berta, 1986). At present, the contact area of forest stands of the researched localities is used as agricultural land sown with more demanding crops, for example, wheat, corn, sunflower, rapeseed, etc.

\section{Experimental sites - studied localities}

1. Velký les - Natura 2000 area: SKUEV0094 (48.095 ha), compact area in the forest cover of the Nitrianska niva (floodplain), cadastral area of the town of Šrany. Part of the area includes PR Vel'ký les 21.09 ha; all areas are under the administration of the landscape-protected area CHKO Dunajské luhy, $125 \mathrm{~m}$ above sea level. According to the Decree of the Ministry of the Environment of the Slovak Republic no. 24/2003, there are habitats of European importance: 91F0 riparian mixed forests of Quercus robur, Ulmus laevis and U. minor, Fraxinus excelsior or F. angustifolia, along the great rivers and $91 \mathrm{G} 0^{*}$ Carpathian and Pannonic oak-hornbeam forests (Pannonic woods with Quercus petraea and Carpinus betulus). 
2. Dolný háj - Natura 2000 area: SKUEV0085 (58.240 ha), Žitavská pahorkatina, cadastral area of the municipalities of Černík and Komjatice. The area consists of the northern and southern parts, $125 \mathrm{~m}$ above sea level. It also includes habitats of European importance: 6510 lowland hay meadows, 91F0 riparian mixed forests of Quercus robur, Urtica laevis and U. minor, Fraxinus excelsior or F. angustifolia, along the great rivers and 91G0* Carpathian and Pannonic oak-hornbeam forests (Pannonic woods with Quercus petraea and Carpinus betulus).

3. Horný háj - Natura 2000 area: SKUEV0079 (72.98 ha), Žitavská pahorkatina, cadastral area of Černík municipality, 160-190 m above sea level. It also includes habitats of European importance: $40 \mathrm{~A} 0^{*}$ Subcontinental peri-Pannonic scrub, 91G0* Carpathian and Pannonic oak-hornbeam forests (Pannonic woods with Quercus petraea and Carpinus betulus), 91I0 * steppic woods with Quercus spp. and 91M0 Pannonian-Balkanic turkey oak-sessile oak forests.

\section{Phytosociological and ecological approach}

Phytocenological research of vegetation of selected forest stands in Vel'ký les, Dolný háj and Horný háj (Fig. 2), including European important habitats, took place in the months from April to October in the years 2018-2019. The criteria for selecting the location of records were the areas of stands, managed with different intensity and with a different representation of native and non-native, especially invasive species. Phytocenological records were made by the method of the Zürich-Montpellier school using a modified seven-degree (extended by degrees $2 \mathrm{a}, 2 \mathrm{~b}, 2 \mathrm{~m}$ ) Braun-Blanquet scale of coverage and abundance (Moravec et al., 1994). Scale values were transformed into an ordinal scale according to van der Maarel (Maarel, 2005). For sampling of the forest communities, we chose a standard size of $25 \times 25 \mathrm{~m}$. We subsequently unified the nomenclature of taxa according to the work of Marhold (1998).

Non-native and invasive vascular plants were sorted into respective categories following Medvecká et al. (2012) and Gojdičová et al. (2002), according to which we compiled a table (Table 1) of characteristics (origin, life forms, invasive status, places of first occurrence, time of first occurrence in Slovakia). Map outputs were prepared using the Quantum Gis 2.8 geographic information system (QGIS.org. 2015) in the S-JTSK (JTSK) / Krovak East North geographical coordinate system for EPSG: 5514.

We used the average EIVs (Ellenberg et al., 1992) to determine the impact of ecological habitat characteristics on biodiversity (species richness, Shannon-Wiener index, Simpson dominance index, taxonomic diversity and evenness index). After importing phytocenological records into the Juice program (Tichý, 2002), we exported the average EIVs (light, temperature, continentality, moisture, soil reaction and nutrients) using the Ellenb.txt file. The problem is that the indicator values of species are derived from the properties of habitats, from which we again derive habitat characteristics. The solution is, for instance, the use of EIV in ordination analyses as supplementary variables. As stated by Zelený (2012), derived EIVs have a higher value than measured values because the derived (calculated) values consist of two components: a) own EIV and b) value derived from the species composition of phytocenological records. To eliminate the excessive influence of species composition, Zelený (2012) and Zelený and Schaffers (2012) offer the use of the Modified Permutation Test (MoPeT) program (software for MoPeT of significance of mean Ellenberg values, available at: https://www.davidzeleny.net/wiki/doku. php/eiv:software). MoPeT requires $\mathrm{R}$ program installed; it is launched from Juice after setting the External program Paths in the Option menu. The modified null hypothesis is $\mathrm{H}_{0}$ : variable $\mathrm{x}$ (=score of entries on ordination axes), which is not related to that part of the EIV information which is derived from the ecological properties of individual species (the modified test changes the null hypothesis from 'there is no statistical relationship between variable $\mathrm{X}$ and mean EIVs' to 'variable $\mathrm{X}$ is not related to the information based on external ecological data in mean EIVs'). In Juice program, we further calculated the count of species, Shannon-Wiener $\left(\mathrm{H} \leftarrow=-\Sigma p_{i} \ln p_{i}\right.$, $p i$ is the proportion of the individual species cover relative to the total cover) and Simpson domination index (Ds $\left.=\Sigma p_{i}^{2}\right)$. The program also calculates Shannon's equitability/evenness (E) proposed by Tichý and Jason (2006); E is calculated by dividing $\mathrm{H}^{\prime} / \mathrm{H}^{\prime} \max$ (H'max $=\ln s$, where $s$ is the number of species). Taxonomic diversity index $\left(\mathrm{TD}_{\mathrm{D}}\right)$ was calculated based on Clark and

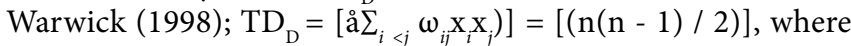
$\mathrm{x}_{i}(i=1,1 / 4, s)$ denotes abundance of the $i$ th species, $\mathrm{n}\left(=\sum_{i} \mathrm{x}_{i}\right)$ is the total number of individuals in the sample and $\omega_{i j}$ distinctness weight. In contrast to the above indices, based on species richness and relative abundance or dominance, the $\mathrm{TD}_{\mathrm{D}}$ index randomises the 'taxonomic distance' of species $i$ and $j$ in the classification system as well as the total number of individuals in the sample. We calculated the index in the Past program (Hammer et al., 2001), which is limited by the number of six taxonomic levels (e.g. genus - family - order - class $1 / 4$ ); the numerical values of the index are similar to the values of the Shannon-Wiener index. To obtain information about the degree of taxonomic variability of the sample, it is necessary to group the names of taxa in the given column; if the number of taxonomic levels is exceeded, the program displays an error message.

Invasive status (cas - casual, nat - naturalised, inv - invasive) of the species in the records are made following Medvecká et al. (2012) and Gojdičová et al. (2002), in analyses were coded as dummy variables. Because CANOCO5 (Ter Braak, Šmilauer, 2018) requires the classification of all variables, we have added a category for autochthonous species. Similarly, we classified the localities of phytosociological relevés: invaded (with the occurrence of two or more invasive species with cover-abundance values of more than 1 Braun-Blanquet scale, $n=44$ relevés), non-invaded (without the occurrence of invasive species, $\mathrm{n}=$ 25 ) and 'transitive' (ad hoc category with the occurrence of one invasive species up to the cover-abundance value of 1 ). Correlation relationships and statistical significance between EIV, biodiversity and phytocenological records were determined using CANOCO5 program tools (Ter Braak, Šmilauer, 2018). Ordination analyses (unconstrained or constrained analyses) were selected according to the length of the gradient (standard deviation units [SDU]) and the purpose of the statistical survey. The statistical significance of explanatory variables was tested by the Monte Carlo permutation test (stepwise selection, number of permutations $499, p<0.05$ ); response variables consist of a set of 228 plant species. The success of the model (the value of the explained variation) is given by the coefficient of determination $\left(R^{2}\right)$ in its adjusted form $\left(R_{\text {adj }}^{2}\right)$. Its value is lower compared to 
Table 1. Identified non-native plant species of the investigated forest stands and their characteristics.

\begin{tabular}{|c|c|c|c|c|c|c|c|}
\hline Species name & IS & RT & TI & LF & Origin & \multirow{2}{*}{$\begin{array}{c}\text { Category } \\
\text { Gojdičová et al. (2002) }\end{array}$} & \multirow[t]{2}{*}{$\$$} \\
\hline & \multicolumn{5}{|c|}{ Medvecká et al. (2012) } & & \\
\hline Ailanthus altissima & inv & neo & 1850 & $\mathrm{Ph}$ & As & $1 \mathrm{a}$ & $\$$ \\
\hline Amaranthus powellii & nat & neo & 1935 & $\mathrm{~T}$ & CAm SAm & - & \\
\hline Ambrosia artemisiifolia & inv & neo & 1949 & $\mathrm{~T}$ & NAm & $1 \mathrm{a}$ & $\$$ \\
\hline Arctium lappa & nat & arch & - & $\mathrm{He}$ & E As & - & \\
\hline Asclepias syriaca & inv & neo & 1917 & G & As & $1 \mathrm{a}$ & $\$$ \\
\hline Aster lanceolatus & inv & neo & 1865 & $\mathrm{He}$ & NAm & $1 \mathrm{a}$ & \\
\hline Atriplex sagittata & nat & arch & B & $\mathrm{T}$ & E As & $1 \mathrm{a}$ & \\
\hline Ballota nigra & nat & arch & - & $\mathrm{He}$ & E As Af & $1 \mathrm{~b}$ & \\
\hline Bromus arvensis & nat & arch & $\mathrm{N}$ & $\mathrm{THe}$ & E As & 5 & \\
\hline Bromus sterilis & nat & arch & $\mathrm{N}$ & $\mathrm{THe}$ & E As & $1 \mathrm{~b}$ & \\
\hline Capsella bursa-pastoris & nat & arch & - & $\mathrm{T}$ & $\mathrm{E}$ & - & \\
\hline Carduus acanthoides & nat & arch & - & $\mathrm{He}$ & E As & - & \\
\hline Celtis occidentalis & nat & neo & 1840 & $\mathrm{Ph}$ & NAm & 3 & \\
\hline Cichorium intybus & nat & arch & - & $\mathrm{He}$ & E As Af & $1 b$ & \\
\hline Convolvulus arvensis & nat & arch & I & $\mathrm{He} \mathrm{G}$ & E As Af & - & \\
\hline Conyza canadensis & inv & neo & 1791 & $\mathrm{~T}$ & NAm & $1 \mathrm{a}$ & \\
\hline Datura stramonium & nat & neo & $16 c$ & $\mathrm{~T}$ & $?$ & 2 & \\
\hline Digitaria sanguinalis & nat & arch & $\mathrm{B}$ & $\mathrm{T}$ & E As Af & - & \\
\hline Echinochloa crus-galli & inv & arch & $\mathrm{N}$ & $\mathrm{T}$ & E As & - & \\
\hline Epilobium ciliatum & inv & neo & 1946 & $\mathrm{He}$ & NAm CAm & 2 & \\
\hline Fallopia convolvulus & nat & arch & $\mathrm{N}$ & $\mathrm{T}$ & E As & - & \\
\hline Fraxinus americana & nat & neo & 1804 & $\mathrm{Ph}$ & NAm & - & \\
\hline Fraxinus pennsylvanica & nat & neo & 1870 & $\mathrm{Ph}$ & NAm & 2 & \\
\hline Galega officinalis & nat & neo & 1791 & $\mathrm{He}$ & $\mathrm{E}$ & 6 & \\
\hline Gleditsia triacanthos & nat & neo & 1806 & $\mathrm{Ph}$ & NAm & 3 & \\
\hline Helianthus tuberosus & inv & neo & 1830 & $\mathrm{He}$ & NAm & $1 \mathrm{a}$ & \\
\hline Chenopodium strictum & nat & neo & - & $\mathrm{T}$ & As & 2 & \\
\hline Chenopodium urbicum & nat & arch & B & $\mathrm{T}$ & E As & - & \\
\hline Impatiens parviflora & inv & neo & 1897 & $\mathrm{~T}$ & As & $1 \mathrm{a}$ & \\
\hline Juglans nigra & nat & neo & 1770 & $\mathrm{Ph}$ & NAm & 3 & \\
\hline Juglans regia & nat & arch & $\mathrm{M}$ & $\mathrm{Ph}$ & E As & - & \\
\hline Lactuca serriola & nat & arch & $\mathrm{M}$ & $\mathrm{THe}$ & E As Af & - & \\
\hline Lamium purpureum & nat & $\operatorname{arch}$ & $\mathrm{R}$ & $\mathrm{T}$ & E As Af & - & \\
\hline Melilotus officinalis & nat & arch & - & $\mathrm{He}$ & E As & $1 \mathrm{~b}$ & \\
\hline Mercurialis aпnиа & nat & arch & - & $\mathrm{T}$ & E As Af & - & \\
\hline Negundo aceroides & inv & neo & 1794 & $\mathrm{Ph}$ & NAm & $1 \mathrm{a}$ & $\$$ \\
\hline Parthenocissus quinquefolia & nat & neo & 1897 & $\mathrm{Ph}$ & NAm & 2 & \\
\hline Philadelphus coronarius & cas & neo & 1847 & $\mathrm{Ph}$ & $\mathrm{E}$ & 4 & \\
\hline Phytolacca americana & nat & neo & 1830 & $\mathrm{GHe}$ & NAm & 2 & \\
\hline Populus $x$ canadensis & nat & neo & 1800 & $\mathrm{Ph}$ & $\mathrm{HC}$ & 6 & \\
\hline Prunus insititia & cas & arch & $\mathrm{M}$ & $\mathrm{Ph}$ & As & 4 & \\
\hline Quercus rubra & nat & neo & 1855 & $\mathrm{Ph}$ & NAm & 3 & \\
\hline Reseda lutea & nat & arch & $\mathrm{R}$ & $\mathrm{He}$ & E As Af & - & \\
\hline Robinia pseudoacacia & inv & neo & 1720 & $\mathrm{Ph}$ & NAm & $1 \mathrm{a}$ & \\
\hline Setaria pumila & nat & arch & $\mathrm{N}$ & $\mathrm{T}$ & E As & - & \\
\hline Solanum nigrum & nat & arch & $\mathrm{N}$ & $\mathrm{T}$ & $\mathrm{E}$ & 5 & \\
\hline Solidago canadensis & inv & neo & 1872 & $\mathrm{He}$ & NAm & $1 \mathrm{a}$ & $\S$ \\
\hline Solidago gigantea & inv & neo & 1909 & $\mathrm{He}$ & NAm & $1 \mathrm{a}$ & $\S$ \\
\hline Stenactis annua agg. & - & - & - & - & - & $1 \mathrm{a}$ & \\
\hline Tanacetum vulgare & - & - & - & - & - & $1 b$ & \\
\hline Torilis arvensis & nat & arch & - & $\mathrm{T}$ & $\mathrm{E}$ & - & \\
\hline Verbena officinalis & nat & arch & - & $\mathrm{THe}$ & E As Af & - & \\
\hline Veronica arvensis & nat & arch & - & $\mathrm{T}$ & E As Af & - & \\
\hline Viola odorata & nat & arch & - & $\mathrm{He}$ & E As Af & - & \\
\hline Vitis vulpina & cas & neo & - & $\mathrm{Ph}$ & NAm & 4 & \\
\hline
\end{tabular}

Notes: According to Medvecká et al. (2012): IS - the invasion status; cas - casual; nat - naturalised; inv - invasive; RT - residence time; arch - archaeophyte; neo - neophyte; TI - the time of introduction; LF - the life forms according to the Raunkiær classification; G - geophyte; $\mathrm{He}$ - hemicryptophyte; $\mathrm{Ph}$ - phanerophyte; $\mathrm{T}$ - therophyte; Origin - origin of the taxon; Af - Africa; As - Asia; C - from cultivation (anecophyte); CAm - Central America; E - Europe; H - hybrid; NAm - North America; SAm - South America. According to Gojdičová et al. (2002): 1a invasive neophyte; $1 \mathrm{~b}$ invasive archaeophyte; 2 potentially invasive taxa; 3 plants often escaping from cultivation; 4 plants occasionally escaping from cultivation; 5 accidentally introduced taxa; 6 naturalised taxa; $\$$-invasive plants designated in the Decree of the Ministry of Environment No. 24/2003. 
Table 2. Variables with values of partial (conditional) and marginal (simple) variance as an explanatory variable with a test of their statistical significance $\left(p_{\mathrm{a}}=0.05\right)$. In the RDA model used, the EIV variables explain $R^{2}=20.21 \%$ variability, $R_{\text {adj }}^{2}=15.70 \%$.

\begin{tabular}{|l|c|c|c|c|c|}
\hline \multicolumn{1}{|c|}{ Name } & Explains \% & Contribution \% & Pseudo-F & $\boldsymbol{p}$ & $\boldsymbol{p}_{(\text {adj } j}$ \\
\hline Light & 8.8 & 28.7 & 10.7 & 0.002 & 0.028 \\
\hline Moisture & 5.7 & 18.6 & 7.4 & 0.002 & 0.028 \\
\hline Invaded & 3.4 & 11.1 & 4.5 & 0.002 & 0.028 \\
\hline Count species & 2.3 & 7.4 & 3.1 & 0.002 & 0.028 \\
\hline Nutrients & 2 & 6.4 & 2.7 & 0.002 & 0.028 \\
\hline Soil reaction & 1.2 & 3.9 & 1.7 & 0.006 & 0.084 \\
\hline Temperature & 1.2 & 3.9 & 1.7 & 0.008 & 0.112 \\
\hline Taxonomic diversity & 1.1 & 3.7 & 1.6 & 0.018 & 0.252 \\
\hline Evenness & 1.1 & 3.7 & 1.6 & 0.002 & 0.028 \\
\hline Non-invaded & 1.1 & 3.5 & 1.5 & 0.01 & 0.14 \\
\hline Continentality & 1.1 & 3.5 & 1.5 & 0.02 & 0.28 \\
\hline Simpson & 1 & 3.3 & 1.5 & 0.022 & 0.308 \\
\hline Shannon-Wiener index & 0.7 & 2.4 & 1.1 & 0.332 & 1 \\
\hline
\end{tabular}

Note: $p_{(\text {adj) }}=$ adjusted $p$-values after Bonferroni correction.

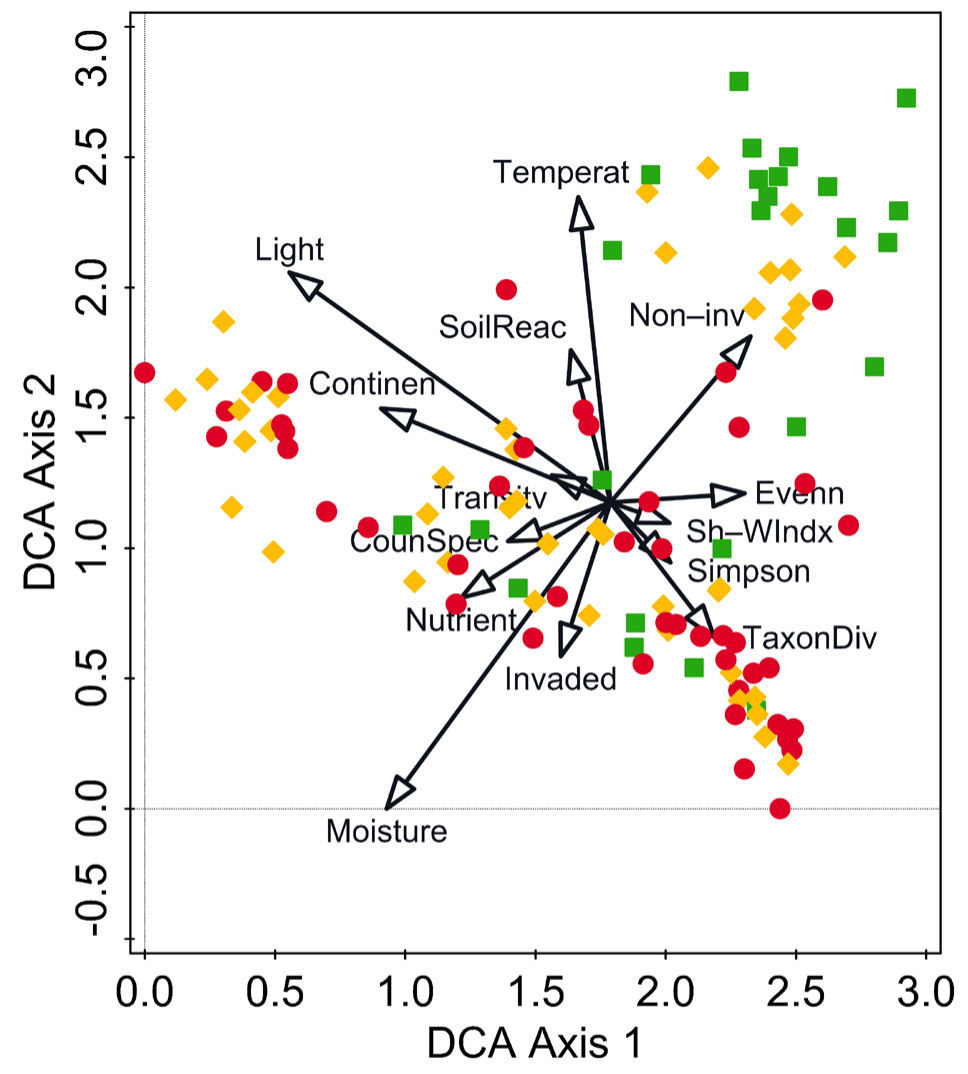

\section{Environmental Variables}

$\triangleright$

Samples

invaded non-invaded $>$ transitive

Fig. 3. Explanatory variables species richness, biodiversity indices and EIVs using as supplementary variables in DCA analysis account for $27.79 \%$ (adjusted explained variation is $18.30 \%$ ). DCA - detrended correspondence analysis, EIVs - Ellenberg's indicator values. 
Table 3. Values of descriptive EIV statistics and diversity indices $(\mathrm{n}=113)$.

\begin{tabular}{|l|c|c|c|c|c|c|c|}
\hline Variables & Average & Median & Minimum & Maximum & SD & Skewness & Kurtosis \\
\hline Count species & 25.788 & 26.000 & 9.000 & 43.000 & 6.452 & 0.076 & 0.020 \\
\hline Shannon-Wiener & 2.498 & 2.499 & 1.284 & 3.528 & 0.438 & -0.367 & 0.374 \\
\hline Simpson & 0.844 & 0.859 & 0.469 & 0.962 & 0.092 & -1.774 & 4.140 \\
\hline Taxonomic diversity & 4.186 & 4.295 & 2.352 & 5.139 & 0.559 & -1.262 & 1.509 \\
\hline Evenness & 0.774 & 0.776 & 0.487 & 0.962 & 0.101 & -0.404 & 0.412 \\
\hline Light & 5.526 & 5.420 & 4.500 & 7.110 & 0.602 & 0.440 & -0.602 \\
\hline Temperature & 5.693 & 5.650 & 5.330 & 6.750 & 0.225 & 1.213 & 3.431 \\
\hline Continentality & 3.841 & 3.800 & 3.250 & 4.850 & 0.275 & 1.020 & 2.072 \\
\hline Moisture & 5.284 & 5.330 & 4.230 & 6.180 & 0.396 & -0.379 & -0.087 \\
\hline Soil reaction & 6.896 & 6.910 & 6.250 & 7.320 & 0.209 & -0.362 & -0.116 \\
\hline Nutrients & 6.486 & 6.530 & 5.000 & 7.360 & 0.437 & -0.549 & 0.514 \\
\hline
\end{tabular}

Note: SD - standard deviation.

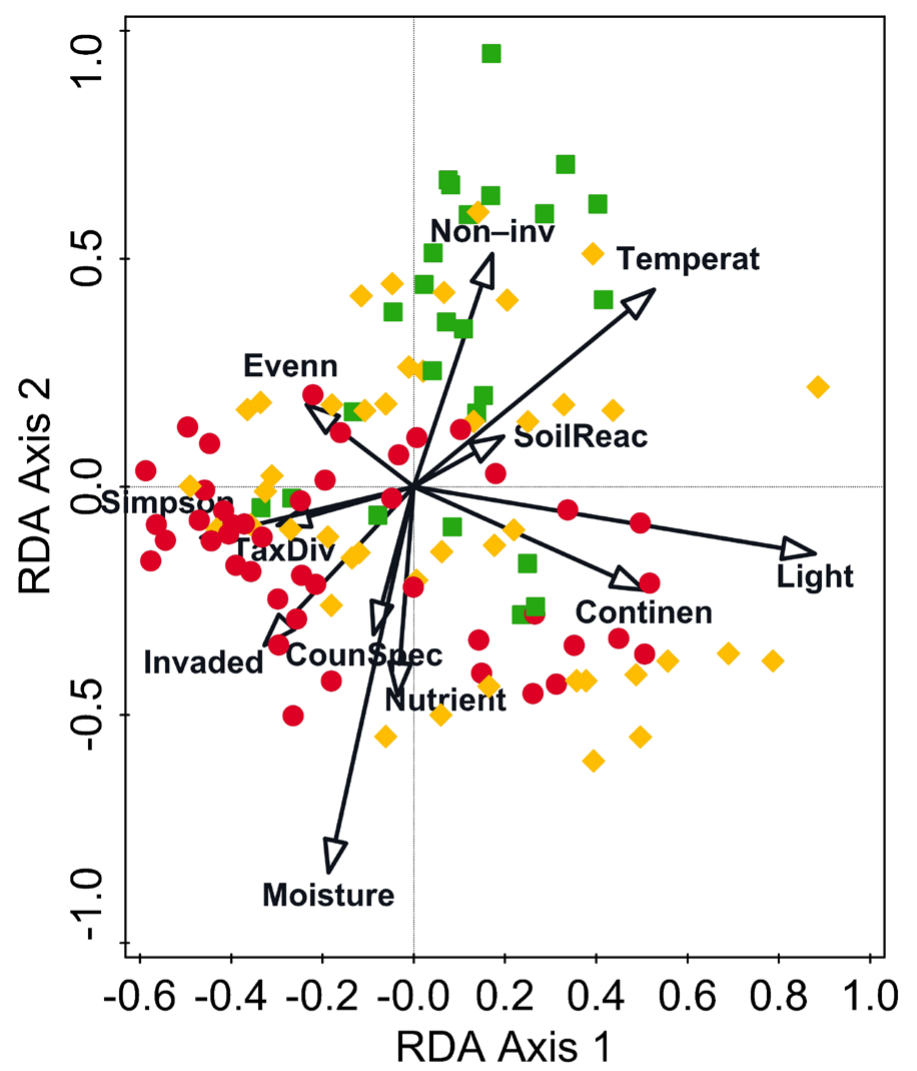

\section{Environmental Variables}

$\triangleright$

Samples

invaded $\quad$ non-invaded $>$ transitive

Fig. 4. Bioplot diagram of limited redundancy analysis of EIV correlation relationships, count of species and rate of forest infestation (samples). The model explains $R^{2}=30.79 \%$ variability, $R_{\text {adj }}^{2}=21.70 \%$. The first ordination axis explains $10.68 \%$ of variability $(p=0.002)$ and the second axis explains $6.65 \%(p=0.002)$. 
Table 4. Normality $(p>0.05)$ of the distribution of values was confirmed for the variables count of species, Shannon-Wiener index, moisture and nutrients, and homogeneity for the variables count of species, temperature, continentality and soil reaction.

\begin{tabular}{|l|c|c|c|c|}
\hline & \multicolumn{2}{|c|}{ Normality } & \multicolumn{2}{c|}{ Homogeneity } \\
\hline Variables & SW-W & $p$-Value & Leven test (F distribution) & $p$-Value \\
\hline Count species & 0.9922 & 0.776 & 0.273 & 0.762 \\
\hline Shannon-Wiener & 0.9802 & 0.0922 & 4.116 & 0.019 \\
\hline Simpson & 0.8498 & $2 \mathrm{E}-09$ & 6.965 & 0.001 \\
\hline Taxon diversity & 0.8971 & $3 \mathrm{E}-07$ & 6.915 & 0.001 \\
\hline Evenness & 0.9741 & 0.0271 & 6.765 & 0.002 \\
\hline Light & 0.9674 & 0.0073 & 4.860 & 0.009 \\
\hline Temperature & 0.9283 & 0.00001 & 2.897 & 0.059 \\
\hline Continentality & 0.9405 & 0.00008 & 1.027 & 0.362 \\
\hline Moisture & 0.9845 & 0.2184 & 5.750 & 0.004 \\
\hline Soil reaction & 0.9765 & 0.0434 & 0.400 & 0.671 \\
\hline Nutrients & 0.98 & 0.0882 & 6.298 & 0.003 \\
\hline
\end{tabular}

Note: Highlighted variables have impaired normality and homogeneity.

Table 5. Statistically significant deviations show unmodified and modified EIVs for moisture, soil reaction and nutrients.

\begin{tabular}{|l|c|c|c|c|}
\hline Variables & KW-H (1;226) & p-Value & F (1;226) & p-Value \\
\hline Light & 1.1632 & 0.2808 & $=$ & $=$ \\
\hline Temperature & 3.3861 & 0.0657 & $=$ & $=$ \\
\hline Continentality & 0.3942 & 0.5301 & $=$ & $=$ \\
\hline Moisture & $=$ & $=$ & 9.0707 & 0.0029 \\
\hline Soil reaction & 7.1652 & 0.0074 & $=$ & $=$ \\
\hline Nutrients & $=$ & $=$ & 7.811 & 0.0056 \\
\hline
\end{tabular}

Note: Deviations of the values of the highlighted variables are statistically significant.

$R^{2}$ (explanatory variables / total inertia), but $R_{\text {adj }}^{2}$ takes into account the sample size and the number of variables, so it is more accurate.

In the Statistika program (StatSoft, Inc., 2009), we used descriptive statistics to determine the characteristics of the position and variability of the data. Normality of data distribution was tested by Shapiro-Wilks test and the homogeneity of variances by Leven test. Analysis of variance (ANOVA) from mean values was tested by Kruskal-Wallis test and one-way ANOVA. We tested the statistical significance of the differences in the median values and using the Spearman correlation coefficient, we verified the dependencies between the variables. We determined a $95 \%$ level of statistical significance $(p \alpha=0.05)$; where $p>p \alpha$, we did not reject $\mathrm{H}_{0}$ at the determined level of significance.

\section{Results}

In the period from 2018 to 2019 , we recorded 113 phytocenological records in three forest stands, in which there were 200 taxa of vascular plants, 199 at the species level. We recorded the occurrence of 15 invasive and 37 naturalised species. Only three identified species had a casual occurrence in the studied localities
(Table 1), although the majority of the evaluated 880 alien taxa in the flora of Slovakia were casual (507 taxa, 57.6\%) (Medvecká et al., 2012). Invasive trees (phanerophytes) identified in the photographed forest stands included Ailanthus altissima, Negundo aceroides and Robinia pseudoacacia. Non-native woody plants were introduced into the stands through cultivation and zoochorism: Celtis occidentalis, Juglans nigra, Fraxinus americana, F. pennsylvanica, Parthenocissus quinquefolia, Philadelphus coronarius, Populus x canadensis, Prunus insititia and Quercus rubra.

We obtained data on the heterogeneity of the data set and the spatial visualisation of the entries by unconstrained detrended correspondence analysis (DCA). We supplemented the visualisation with our selected explanatory variables, which we used as supplementary variables using the classification of phytocenological relevés (invaded, non-invaded, transitive; Fig. 3). The highest value of the gradient length after logarithmic data transformation (length of gradient $=\mathrm{SDU}$ ) was 2.92 , total variation = $4.46 \%$, and the short gradient was suitable for linear ordination methods. The ordination showed that the dispersion of the obtained phytocenological record data was agglomerated.

Using the constrained ReDundancy Analysis (RDA) method, we tested the statistical significance of selected EIVs as explanatory variables with Monte Carlo permutation test by gradual selection of interactive-forward selection (species $\sim$ environmental variables) using the procedure of forward selection of explanatory variables. Table 2 shows the variables with explained variability, where the other variables are covariates and the contribution of variability to the total variability is explained by the selected explanatory variables. They are ranked according to the values of the explained variability and are statistically significant $(p<0.05) ; \mathrm{H}_{0}$ : the partial contribution of EIVs to the overall variability is not higher than random. The selected variables explain $30.79 \%$ of the variability of our model, with its adjusted value being $21.70 \%$. For comparison, we also present the adjusted values of Bonferroni by correcting the multiple regression $p(\mathrm{adj})$, which significantly increases the level of statistical significance. Of the 12 statistically significant values after the correction, six variables remained statistically significant. 
Table 6. Results of testing of the differences in mean values of selected environmental factors extracted from phytocenological records $(\mathrm{n}=113$ ) of invaded and non-invaded vegetation by Kruskal-Wallis and ANOVA (F) test $\left(p_{\mathrm{a}}=0.05\right)$.

\begin{tabular}{|l|c|c|c|c|}
\hline Variables & KW-H (1;226) & $\mathbf{p}$-Value & $\mathbf{F ~ ( 2 ; 2 2 3 ) ~}$ & $\mathbf{p}$-Value \\
\hline Count species & $=$ & $=$ & 28.0452 & 0.0000 \\
\hline $\begin{array}{l}\text { Shannon-Wiener } \\
\text { index }\end{array}$ & $=$ & $=$ & 8.9037 & 0.0002 \\
\hline Simpson index & 7.2786 & 0.0263 & $=$ & $=$ \\
\hline Taxon diversity & 8.4188 & 0.0149 & $=$ & $=$ \\
\hline Evenness & 0.1559 & 0.9250 & $=$ & $=$ \\
\hline Light & 1.353 & 0.5084 & $=$ & $=$ \\
\hline Temperature & 2.9716 & 0.2263 & $=$ & $=$ \\
\hline Continentality & 5.1826 & 0.0749 & $=$ & $=$ \\
\hline Moisture & $=$ & $=$ & 5.8337 & 0.0034 \\
\hline Soil reaction & 11.3004 & 0.0035 & $=$ & $=$ \\
\hline Nutrients & $=$ & $=$ & 4.428 & 0.0130 \\
\hline
\end{tabular}

Note: Differences in the mean values of the highlighted variables are statistically significant.

The EIVs presented in Table 2 (supplemented by numerical and categorical variables of invaded and non-invaded vegetation) are plotted in a limited linear redundancy model in Fig. 4. The displayed vectors (variables) provide information about their mutual correlation relations and correlation to classified record localities. The highest contribution to the explained data variability is provided by EIV light (explains $8.8 \%$, contribution 28.7\%, $p=0.002$ ) and moisture (explains 5.7\%, contribution $18.6 \%, p=0.002)$. The first ordination axis explains $10.03 \%$ of the variability, the second $16.38 \%$ of the cumulative variability and the fourth ordination axis $21.48 \%$ of the cumulative variability. The vector of the transitive variable is not shown in the ordination graph due to collinearity, Shannon-Wiener index and also due to the high value of the inflation factor (IF) $>10$.

Using the descriptive statistics tool in the Statistika.cz program, we determined the measures of variability and position of EIV and biotic indices (Table 3). We used EIV adjusted by $\mathrm{MoPeT}$ and we did not distinguish the naturalness category (invaded, non-invaded, transitive).

According to their scaling, the values of the median EIV in Table 3 have corresponding characteristics for the habitats of the investigated forest stands as follows: light $-5.4=$ partial shade, temperature $-5.7=$ transition to warm areas of lowlands to highlands level, continentality $-3.8=$ occupancy of subocean and continental non-distinctive species, humidity $-5.3=$ species of intermediate habitats, soil reaction -6.9 $=$ neutral soils and nutrients $-6.5=$ predominantly eutrophic habitats. With a right-hand skew (positive), we pointed out the asymmetry and predominance of smaller numbers in temperature and continentality (the median is smaller than the average). Thus, most of the values of the measured variables temperature and continentality are smaller than the average. The Simpson index and taxonomic diversity had a left-hand skew (negative), which indicates the predominance of larger numbers in the data set (median is greater than the average). The leptokurtic distribution (+ values) of the peaks for temperature, continentality, Simpson and taxonomic diversity shows the concentration of numbers at the median, less variability of values and the presence of extreme numbers in the data set. For the other variables like count species, Shannon-Wiener, evenness, light, moisture, soil reaction and nutrients, we pointed out less asymmetry of values based on the zero values of skewness and kurtosis.

To find the impact of non-native invasive species on the vegetation of our researched forest stands, we will further exarmine whether the following differ: (i) values of unmodified and modified (MoPeT) EIVs and (ii) mean values of our chosen variables between invaded and non-invaded vegetation; we will also determine (iii) whether there are statistically significant correlations between the variables of invaded and non-invaded vegetation. We selected suitable methods based on the results of testing the normality and homogeneity of the data set. We verified the null hypothesis of a normal distribution with the Shapiro-Wilk $\mathrm{W}$ test and tested the homogeneity of the dependent variables with the Leven test (Fisher's distribution of sample variances was used) (Table 4). It is a prerequisite for the use of parametric or nonparametric tests of ANOVA $\left(\mathrm{H}_{0}\right.$ : the data come from a normal distribution and the homogeneity of the variances is not disturbed).

We wanted to find out whether the EIVs exported from the Juice program and the EIVs adjusted by MoPeT differed. We used 2D graph Means with Error plots; the null hypothesis is $\mathrm{H}_{0}$ : the average values of modified and unmodified EIVs do not differ. We found a statistically significant difference $\left(p^{* *}\right)$ in EIV moisture, soil reaction and nutrients (Table 5).

We assume that the presence of invasive species is manifested by a statistically significant deviation of the mean values of our selected variables between phytocenological records, which were photographed for the invaded and non-invaded vegetation. In this case, we also expect differences in the values of biodiversity indices calculated from the synoptic table. We used the graph Means with Error plots to test the deviations of the mean values. The null hypothesis is $\mathrm{H}_{0}$ : the average values of the variables of invaded and non-invaded stands do not differ. Due to disruption of the normality and homogeneity of some variables, we used the nonparametric Kruskal-Wallis test, supplemented by the F test (Table 6). There was a statistically significant difference $\left(p^{\star}\right)$ between invaded and non-invaded vegetation in the variables: count of species, Shannon-Wiener index, Simpson index dominance and taxonomic diversity, from EIVs are significant only in moisture and soil reaction.

The results of the analysis by the Kruskal-Wallis test as shown in Table 6 confirmed statistically significant differences in the mean values between count species, Shannon-Wiener index, Simpson index and taxonomic diversity. For EIV, these included the values of the factors moisture and soil reaction of invaded and non-invaded vegetation. However, there is a lack of information between which grouping variables (invaded, transitive and noninvaded plant communities) there were statistically significant differences. In order to obtain the required information, we performed a post-hoc Scheffe test and the results are shown in Table 7. Statistically significant differences were obtained, for example, in the following factors: count species (invaded and transitive vegetation), Shannon-Wiener index (invaded and transitive vegetation) and Simpson index (invaded and non-invaded vegetation). 
Table 7. Post-hoc tests of grouping factors of invaded, non-invaded and transitive vegetation captured by phytocenological relevés.

\begin{tabular}{|c|c|c|c|c|}
\hline Variables & & Invaded & Transitive & Non-invaded \\
\hline \multirow{3}{*}{ Count species } & Invaded & & 0.5654 & 0.0000 \\
\hline & Transitive & 0.5654 & & 0.0000 \\
\hline & Non-invaded & 0.0000 & 0.0000 & \\
\hline \multirow{3}{*}{$\begin{array}{l}\text { Shannon-Wiener } \\
\text { index }\end{array}$} & Invaded & & 0.5654 & 0.0000 \\
\hline & Transitive & 0.5654 & & 0.0000 \\
\hline & Non-invaded & 0.0000 & 0.0000 & \\
\hline \multirow{3}{*}{ Simpson index } & Invaded & & 0.2854 & 0.0010 \\
\hline & Transitive & 0.2854 & & 0.0564 \\
\hline & Non-invaded & 0.0010 & 0.0564 & \\
\hline \multirow{3}{*}{ Taxonomic diversity } & Invaded & & 0.1111 & 0.0018 \\
\hline & Transitive & 0.1111 & & 0.1935 \\
\hline & Non-invaded & 0.0018 & 0.1935 & \\
\hline \multirow{3}{*}{ Evenness } & Invaded & & 0.9574 & 0.5230 \\
\hline & Transitive & 0.9574 & & 0.6742 \\
\hline & Non-invaded & 0.5230 & 0.6742 & \\
\hline \multirow{3}{*}{ Light } & Invaded & & 0.9940 & 0.3001 \\
\hline & Transitive & 0.9940 & & 0.2588 \\
\hline & Non-invaded & 0.3001 & 0.2588 & \\
\hline \multirow{3}{*}{ Temperature } & Invaded & & 0.5702 & 0.0337 \\
\hline & Transitive & 0.5702 & & 0.2297 \\
\hline & Non-invaded & 0.0337 & 0.2297 & \\
\hline \multirow{3}{*}{ Continentality } & Invaded & & 0.6193 & 0.0695 \\
\hline & Transitive & 0.6193 & & 0.3320 \\
\hline & Non-invaded & 0.0695 & 0.3320 & \\
\hline \multirow{3}{*}{ Moisture } & Invaded & & 0.9034 & 0.0174 \\
\hline & Transitive & 0.9034 & & 0.0056 \\
\hline & Non-invaded & 0.0174 & 0.0056 & \\
\hline \multirow{3}{*}{ Soil reaction } & Invaded & & 0.3336 & 0.0018 \\
\hline & Transitive & 0.3336 & & 0.0678 \\
\hline & Non-invaded & 0.0018 & 0.0678 & \\
\hline \multirow{3}{*}{ Nutrients } & Invaded & & 0.7873 & 0.0693 \\
\hline & Transitive & 0.7873 & & 0.0155 \\
\hline & Non-invaded & 0.0693 & 0.0155 & \\
\hline
\end{tabular}

Note: There are statistically significant differences in the highlighted variables $\left(p_{\mathrm{a}}=0.05\right)$.

For Ellenberg econumbers, there were statistically significant differences in temperature (invaded and non-invaded vegetation).

To determine the statistically significant correlations between variables (Simpson, taxonomic diversity, evenness index, light, temperature, continentality and soil reaction), we used a nonparametric Spearman test (due to violation of normality and increased data homogeneity) of the order correlation between all selected variables. Using the parametric Pearson $r$ correlation coefficient, we determined the relationship between the selected variables (count of species, Shannon-Wiener index, moisture and nutrients) (Table 8). From the results, we found a very strong relationship between count of species and Shannon-Wiener in$\operatorname{dex}(r=0.724)$ and medium relationship between count of species and Simpson index $(r=0.531)$ and taxonomic diversity $(r=$ 0.477). Non-invaded stands showed a negative (weak) growth to the count of species and biotic indices. With respect to the habi- tat characteristics, these included the moisture factor, increased soil salinity (soil reaction) and increased nutrients (nutrients).

\section{Conservation-important species}

As part of the research of forest stands, we also registered the occurrence of conservation-important species in the original parts of the forest, rarely in monocultures. We searched for species in the list of endangered species (Eliáš jun. et al., 2015) and assigned them the appropriate threat categories. Paragraph mark represents a species protected by law (MoE SR, 2003): Epipactis helleborine - LC (Least Concern)/\$, Epipactis voethii - LC/\$, Viola elatior - EN (Endangered)/\$, Cephalanthera longifolia NT (Near Threatened)/\$, Clematis integrifolia NT/\$, Convallaria majalis LC, Galanthus nivalis - LC, Platanthera bifolia - LC, Odontites vernus - VU (vulnerable) and Scilla bifolia - LC. 
Table 8. Statistically significant $(p<0.05)$ coefficients of Spearman nonparametric correlation (disturbed normality and/or homogeneity), and Pearson (variables: count of species, Shannon-Wiener index and Ellenberg indicator values) parametric correlations of factors are highlighted.

\begin{tabular}{|c|c|c|c|c|c|c|c|c|c|c|c|c|c|c|}
\hline Variabl & ount & h-W & Ds & TD & E & $\mathbf{L}$ & $\mathrm{T}$ & $\mathrm{C}$ & $\mathbf{M}$ & $\mathrm{Sr}$ & $\mathbf{N}$ & Inv. & Non-inv. & Trans. \\
\hline Count & 1000 & 0724 & 0.531 & 0.477 & .310 & .217 & .040 & .023 & 0.069 & .251 & .022 & 0.211 & & 0.162 \\
\hline Sh-W & & & 53 & 320 & 374 & 0.014 & 0.025 & -0.052 & & & -0.090 & & & \\
\hline Ds & & & & & & & & & & & & & & 0.009 \\
\hline $\mathrm{TD}$ & & & & & & & & & & & & & & \\
\hline $\mathrm{E}$ & 10 & 0.874 & 0.923 & 0.769 & 1.000 & -0.082 & 0.036 & -0.051 & -0.228 & 0.053 & -0.139 & 0.023 & & -0.004 \\
\hline $\mathrm{L}$ & & & -0.065 & -0.217 & & 1.000 & 551 & & & 0.302 & & & & 0.053 \\
\hline $\mathrm{T}$ & & 0.025 & -0.003 & -0. & 36 & & & & & 0.319 & & -0.103 & & 0.027 \\
\hline $\mathrm{C}$ & 23 & -0.052 & -0.081 & -0.108 & -0.051 & 300 & 0.229 & .000 & -0.035 & 0.017 & -0.274 & 0.128 & & -0.018 \\
\hline$M$ & & & & & & & & & & & & & & \\
\hline $\mathrm{Sr}$ & & & & & & 0.302 & & & -0.221 & & 82 & 62 & & 0.016 \\
\hline $\mathrm{N}$ & 0.022 & -0.090 & -0.074 & -0.138 & -0.139 & 0.062 & -0.188 & -0.274 & 0.509 & 0.063 & 1.000 & 0.033 & - & 0.096 \\
\hline Inv. & & & & & & 0.010 & & & & & 0.033 & 1.000 & & -0.638 \\
\hline Non-inv. & 0.439 & -0.240 & -0.166 & -0.170 & -0.022 & -0.074 & 0.090 & -0.129 & -0.201 & -0.209 & -0.152 & -0.426 & 1.000 & -0.426 \\
\hline Trans. & 0.162 & 0.055 & 0.009 & -0.012 & -0.004 & 0.053 & 0.027 & -0.018 & 0.106 & 0.016 & 0.096 & -0.638 & -0.426 & 1.000 \\
\hline
\end{tabular}

Notes: Count - count of species; Sh-W - Shannon-Wiener index; Ds - Simpson index; TD - taxonomic diversity; E - Shannon evenness; L - light; T - temperature; C - continentality; M - moisture; $\mathrm{Sr}$ - soil reaction; N - nutrients; inv. - invaded plant communities; non-inv. non-invaded; trans. - transitive. The highlighted variables are statistically significant $\left(p_{\mathrm{a}}=0.05\right)$.

\section{Discussion}

The researched forest stands were selected after consultation with the administration of the protected landscape CHKO Dunajské luhy. They are part of the Natura 2000 network in the locality: 1 - Velký les, 2 - Dolný háj and 3 - Horný háj. By analysing 113 phytocenological records, we determined 199 species of vascular plants, of which, according to Medvecká et al. (2012) and Gojdičová et al. (2002), there were 15 invasive and 37 naturalised species. These represented taxa that occurred in riparian forests in Europe with a high frequency and in large areas (Jarolímek, 1993; Paunović et al., 2015; Dyakov, Zhelev, 2013). We did not record invasive neophytes of Impatiens glandulifera and species of the genus Fallopia.

For statistical investigation, we processed the obtained phytocenological data by standard procedures in the Juice program (export of EIVs). When using and interpreting the EIVs, it is necessary to keep in mind the so-called argumentation by circles, especially in correlation analyses (Zelený, 2012; Bartelheimer, Poschlod, 2016). It consists of the fact that the properties of species are derived from the properties of habitats, by means of which we again derive the properties of other habitats. The derived EIVs have a higher value than the measured EIVs because in addition to the ecological properties of the habitat, they are increased by the species composition of phytocenological relevés. To remove the redundant second component, Zelený and Schaffers (2012) proposed the MoPeT program. We tested whether there was a statistically significant difference between the values of modified and unmodified EIV. We found a statistically significant difference $\left(p^{* *}\right)$ for EIV moisture, soil reaction and nutrients. The factors of light, temperature and continentality have become inconclusive. A similar result was found (apart from EIV Light) by Zelený (2012).
Spatial visualisation of records, their correlations and heterogeneity of input data were determined using detrended correspondence analysis (DCA). We supplemented the DCA of vegetation records with the following factors (Fig. 3): EIVs, invaded, non-invaded and transitive phytocenological relevés, count species and ecological indices (Shannon-Wiener, Simpson and evenness). We used environmental factors as passive variables (supplementary variables). The distribution of non-invaded and invaded records based on their species composition is indicated. Transitive records are distributed throughout the ordination space. According to the length of the vectors, the EIVs moisture, light and temperature are significant. Ecological indices are correlated as expected. Invaded vegetation (invasive species) prefers moist habitats with higher nutrient content and lower temperature. After the logarithmic transformation of the data, the length of the gradient is 2.92. It is appropriate to use linear ordination methods. In constrained RDA, we tested the statistical significance of selected Monte Carlo EIVs by an interactive-forward selection permutation test. Statistically significant $\left(p_{\mathrm{a}}=0.05\right)$ EIVs included light, moisture, nutrients, soil reaction, temperature and continentality. Light, moisture and nutrients remained statistically significant after using the multiple regression correction (Bonferroni). The highest contribution to the explained total variability came from the factor light $=8.8 \%$; of the evaluated factors, it represented $28.7 \%$. The success of our model is indicated by the coefficient of determination $R^{2}=20.21 \%$ of the explained variability. CANOCO5 also calculates its adjusted value $R_{\text {adj }}^{2}=15.70 \%$. The adjusted value is smaller - unlike $R^{2}$, it takes into account the number of variables in the model - so it is more accurate.

The aim of our study is to determine, among other things, whether selected variables (count of species, Shannon-Wiener index, Simpson index, taxonomic diversity and modified EIVs) 
of invaded and non-invaded stands recorded by phytocenological records show statistically significant deviations. According to the skewness, low values are dominant in the data set for the variables count of species, light, temperature and continentality (Table 3). Another measure of variability is kurtosis with negative values $(\mathrm{k}<0$, not concentrated around the mean value) for the factors light, moisture and soil reaction. The median value of statistically significant EIVs corresponds to the following characteristics: light- $5.4=$ partial shade, temperature- $5.7=$ transition to warm areas of planar to highland zone, humidity$5.3=$ species of intermediate habitats and soil reaction- $6.9=$ neutral soil. Testing of mean deviations using the graph Means with Error plots with Kruskal-Wallis and F test confirmed statistically significant differences $\left(p^{*}\right)$ between records with invaded and non-invaded vegetation $(n=113)$ for the variables count species, Shannon-Wiener Index, Simpson and taxon diversity. In case of EIV, these are the values of the factors moisture and soil reaction. Statistically significant differences were obtained in the following variables: count species (invaded $x$ non-invaded, invaded $x$ transitive), Shannon-Wiener index (invaded $\times$ non-invaded, transitive $\times$ non-invaded), Simpson index (invaded $\times$ non-invaded) and taxomomic diversity (noninvaded $\times$ transitive) (Table 7 ). For EIVs, these included the following factors: temperature (invaded $\times$ non-invaded), moisture (invaded $\times$ non-invaded, transitive $\times$ non-invaded), soil reaction (invaded $\times$ non-invaded) and nutrients (transitive $\times$ non-invaded). As expected, statistically significant differences predominated between invaded and non-invaded stands (six cases), non-invaded and transient stands (three cases) and invaded and transient stands (two cases).

The count of species (species richness) according to the vector (Fig. 4) increases in the invaded stands, while the change is statistically significant. We believe that this is due to the following factors: (i) mosaic logging interventions in the forest stand, the number of species increases with the progress of successive series of vegetation development after logging; (ii) the noninvaded stands of the associated forest stand with a fallen layer are relatively poor in species and (iii) the invaded stands were also mapped on clearings with undergrowth of both forest species and numerous species of ruderal (R) strategy. Dyderski and Jagodziński (2021) referred to the mature native forests that have naturally low alpha diversity. However, these forests often contain rare and specialised species. According to the authors Chmura and Sierka (2006), a relatively lower number of individuals of invasive herbaceous level is a factor that increases the species richness of invaded stands. They considered the number of individuals of the invasive species to be more important than the total area occupied by it. The exception comes in the form of Impatiens parviflora, which has the highest frequency of occurrence $(58 \%)$ and an average coverage of $15 \%$. It is a broad-leaved herb and the number of individuals is relatively small. This apparent paradox is also confirmed by Spearman or Pearson correlation (according to the results of normality and homogeneity testing) as shown in Table 8 . The count of species is positively correlated with invaded stands. Non-invaded stands show statistically significant negative correlation with biotic indices and the EIVs moisture, soil reaction and nutrients, which are generally known as factors increasing the invasibility of plant communities (Rejmánek et al., 2013; Chytrý, Pyšek, 2009). Highly significant $\left(p^{* * *}\right)$ correlations of biotic in- dices (count of species, Shannon-Wiener index, Simpson index and evenness) and the EIV s light, temperature and moisture, in addition to soil reaction were confirmed by Jastrzębska et al. (2009). The authors researched meadows and pastures in the territory of northeastern Poland. According to the redundancy ordination (Fig. 4, Table 8), the expected statistical significance of the correlation between the number of species and the EIVs moisture and nutrients was not confirmed. We assume that in addition to the factors listed in points (i)-(iii) (see above), there are others. Some were reported by Halarewicz et al. (2021); for example, plants react to habitat changes with a delay and the mean indicator values may not reflect the current state of habitat. Moreover, it needs to be taken into account that there is a strong linear dependency between data pertaining to vegetation and the ecological factors. Therefore, if the gradient is short, even the random variation in species composition might misinterpret the results.

\section{Notes on conservation-important species}

As part of the research of forest stands, we also registered the occurrence of conservation-important species in the original parts of the forest, rarely in monocultures. We searched for species in the list of endangered species (Eliáš jun. et al., 2015) and assigned them the appropriate threat categories. Paragraph mark represents a species protected by law (MoE SR, 2003): Epipactis helleborine - LC/\$, E. voethii - LC/\$, Viola elatior - EN/\$, Cephalanthera longifolia $\mathrm{NT} / \$$, Clematis integrifolia $\mathrm{NT} / \$$, Convallaria majalis - LC, Galanthus nivalis - LC, Platanthera bifolia - LC, Odontites vernus - UV and Scilla bifolia - LC.

\section{Conclusion}

In our study, we focused on the analysis of species richness and diversity of invaded (44 relevés), non-invaded ( 25 relevés) and transitional (44 relevés with the occurrence of one invasive species up to the cover-abundance value of 1) forest communities using diversity indices in relation to habitat factors (EIV). Syntaxonomic and synecological issues of forest stands of Velký les, Dolný háj and Horný háj, which are also Natura 2000 areas, will be addressed in a separate study.

Lowland riparian forest ecosystems are vulnerable to the infiltration of non-native species. We have confirmed the occurrence of 15 invasive species and 37 naturalised species. The herbaceous, shrub and tree levels of the forest stand are invaded, which increases the number of taxa, in contrast to the grass-herbaceous vegetation.

We adjusted the extrapolated EIV by a MoPeT, with lower value of the econumbers expressing their own value. For the statistical evaluation of invaded and non-invaded vegetation, it is appropriate to combine several statistical methods (descriptive statistics, correlation and ordination analysis). To evaluate the success of the used ordination models, we used the adjusted value of the coefficient of determination $\left(R_{\text {adi }}^{2}\right)$. Species richness, indices of dominance, diversity and derived EIV are suitable and sufficiently sensitive metrics and factors for the analysis of invaded and non-invaded vegetation.

Statistically significant differences $\left(p^{\star *}\right)$ between records with invaded and non-invaded forest vegetation were confirmed for the following variables: count species, Shannon- 
Wiener index, Simpson index and taxon diversity. For EIV, these factors included moisture and soil reaction. Count of species was positively correlated with invaded stands $\left(p^{*}\right)$. Non-invaded stands showed statistically significant negative correlation with biotic indices and the EIVs moisture, soil reaction and nutrients.

The species richness of the herbaceous level of uninvolved stands, especially in the clearings, was significantly formed by the types of ruderal (R) strategy. Apart from Impatiens parviflora (average cover 15\%), other invasive species were recorded at low cover values. In competition with invasive species, autochthonous and naturalised species of the R strategy were promoted.

\section{Acknowledgements}

This research was supported by the project VEGA: 2/0018/19 Ecological Analyses of Landscape Acculturation in Slovakia since Early Prehistory until Today.

\section{References}

Bartko, M. (2018). Atlas of recognized poplar clones in Slovakia - Practical guide (in Slovak). Zvolen: Národné lesnícke centrum - Lesnický výskumný ústav Zvolen.

Bartelheimer, M. \& Poschlod P. (2016). Functional characterizations of Ellenberg indicator values - a review on ecophysiological determinants. Funct. Ecol., 30, 506-516. DOI: 10.1111/1365-2435.12531.

Bartz, R. \& Kowarik I. (2019). Assessing the environmental impacts of invasive alien plants: a review of assessment approaches. NeoBiota, 43, 69-99. DOI: 10.3897/neobiota.43.30122.

Berta, J. (1986). Lowland riparian forests - Ulmenion Oberd. 1953 (in Slovak). In J. Michalko, J. Berta \& M. Dezider (Eds.), Geobotanická mapa ČSSR. Slovenská Socialistická Republika. Bratislava: Veda, vydavatel'stvo SAV.

Clark, K.R. \& Warwick R.M. (1998). A taxonomic distinctness index and its statistical properties. J. Appl. Ecol., 35, 523-531. DOI: 10.1046/j.13652664.1998.3540532.x.

DAISE (2019). Inventory of alien invasive species in Europe. https://www.gbif. org/ dataset/39f36f10-559b-427f-8c86-2d28afff68ca.

Dyakov, N. \& Zhelev P. (2013). Alien species invasion and diversity of riparian forest according to environmental gradients and disturbance regime. Applied Ecology and Environmental Research, 11, 249-272. DOI: $10.15666 /$ aeer/1102_249272.

Dyderski, M.K. \& Jagodziński A.M. (2021). Impacts of invasive trees on alpha and beta diversity of temperate forest understories. Biol. Invasions, 23, 235-252. DOI: 10.1007/s10530-020-02367-6.

EC (2020). Communication from the Commission to the European Parlia ment, the Council, the European Economic and Social Committee and the Committee of the Regions, 2020: EU Biodiversity Strategy for 2030 Bringing nature back into our lives. Brussels: European Commission. https://ec.europa.eu/info/strategy/priorities-2019-2024/europeangreen-deal/actions-being-taken-eu/eu-biodiversity-strategy-2030_en.

Eliáš, P. jun., Dítě, D., Kliment, J., Hrivnák, R. \& Feráková V. (2015). Red lis of ferns and flowering plants of Slovakia. Biologia, 70, 218-228. DOI: 10.1515/biolog-2015-0018.

Ellenberg, H., Weber, H.E., Doll, R., Wirth, V., Werner, W. \& Paulissen D. (1992). Zeigerwerte von pflanzen in Mitteleuropa. Scripta Geobotanica, $18,1-248$.

Fehér, A. (2007). Historical reconstruction of expansion of non-native plants in the Nitra river basin (SW Slovakia). Kanitzia, 15, 47-62.

Fehér, A. (2018). Vegetation history and cultural landscapes: case studies from South-west Slovakia. Cham: Springer International Publishing AG. DOI 10.1007/978-3-319-60267-7.

Fehér, A \& Borlea Gh.F. (2018). Two potentially invasive tree species of coppice forests: Ailanthus altissima and Robinia presudoacacia. In A. Unrau, G. Becker, R. Spinelli, D. Lazdina, N. Magagnotti, V.N. Nicolescu, P. Buckley, D. Bartlett \& P.D. Kofman (Eds.), Coppice forests in Europe (pp. 63-71). Freiburg i. Br.: Albert Ludwig University of Freiburg.
Gojdičová, E., Cvachová, A. \& Karásová E. (2002). List of non-native invasive and expansive vascular plants of Slovakia (in Slovak). Ochrana Prírody, 21, 59-79.

Halarewicz, A., Pruchniewicz, D. \& Kawałko D. (2021). Using direct and indirect methods to assess changes in riparian habitats. Forests, 12, 504 DOI: $10.3390 / \mathrm{f} 12040504$.

Hammer, Ø., Harper, D.A.T. \& Ryan P.D. (2001). PAST: Paleontological Statistics software packagefor education and data analysis. Paleontologia Electronica, 4, 1-9. https://palaeo-electronica.org/2001_1/past/issue1_01.htm.

Hrivnák, R., Medvecká, J., Baláži, P., Bubíková, K., Otahelová, H. \& Svitok M. (2019). Alien aquatic plants in Slovakia over 130 years: historical overview, current distribution and future perspectives. NeoBiota, 49, 37-56. DOI: $10.3897 /$ neobiota.49.34318.

Hutárová, D. (2011). Changes in the floristic composition of the stand as a result of disturbance of the riparian forest ecosystem (in Slovak). Životné Prostredie, 45, 212-216.

Chmura, D. \& Sierka E. (2006). Relation between invasive plants and species richness of forest floor vegetation: a study of Impatiens parviflora DC. Pol. J. Ecol., 54, 417-428.

Chytrý, M. \& Pyšek P. (2009). Where do introduced plants spread? 1. Differences in the invasion of large areas (in Czech). Živa, 1, 11-14. https:// ziva.avcr.cz/files/ziva/pdf/kam-se-siri-zavlecene-rostliny-1-rozdily-vinvadov.pdf.

Chytrý, M., Pyšek, P., Tichý, L., Knollová, I. \& Danihelka J. (2005). Invasions by alien plants in the Czech Republic: a quantitative assesment across habitats. Preslia, 77, 339-354.

Chytrý, M., Pyšek, P., Wild, J., Pino, J., Maskell, L.C. \& Vilà M. (2009). European map of alies plant invasions based on the quantitative assessment across habitats. Divers. Distrib., 15, 98-107. DOI: 10.1111/j.14724642.2008.00515.x.

Jarolímek, I. (1993). Community with the dominant Impatiens glandulifera, in Slovakia (in Slovak). Bulletin Slovenskej Botanickej Spoločnosti, 15 30-33.

Jastrzębska, M., Szarejko, T., Hołdyński, C. \& Jastrzębski W.P. (2009). Species diversity in grassland communities under different habitat conditions. Polish Journal of Natural Sciences, 24, 43-59. DOI: 10.2478/v10020-0090005-y.

Jurko, A. (1990). Ecological and socioeconomic evaluation of vegetation (in Slovak). Bratislava: Príroda.

Kanieski, M.R., Longhi S.J. \& Soares P.R.C. (2018). Methods for biodiversity assessment: Case study in an area of Atlantic Forest in Southern Brazil. IntechOpen. DOI: 10.5772/intechopen.71824.

Kočický, D. \& Ivanovič B. (2011). Geomorphological division of Slovakia 1: 500000 (in Slovak), according to E. Mazúr \& M. Lukniš (1986). Geomorfologické členenie SSR a ČSSR. Čast' Slovensko. Bratislava: Slovenská kartografia. https://apl.geology.sk/mapportal/img/pdf/tm19a.pdf.

Liebhold, A.M., Brockerhoff, E.G., Kalisz, S., Nuñez, M.A., Wardle, D.A. \& Wingfiel M.J. (2017). Biological invasions in forest ecosystems. Biol. Invasions, 19, 3437-3458. DOI: 10.1007/s10530-017-1458-5.

Maarel van der, E. (2005). Vegetation ecology - an overview. In E. van der Maarel. (Ed.), Vegetation ecology (pp. 1-51). Oxford: Blackwell Publishing UK.

Maglocký, Š. (2002). Potential natural vegetation 1: 500,000 (in Slovak). In T. Hrnčiarová (Ed.) et al., Atlas krajiny Slovenskej republiky. Bratislava: MŽP SR, Banská Štiavnica: SAŽP, ESPRIT.

Marhold, K. (1998). Ferns and flowering plants. In K. Marhold \& F. Hindák (Eds.), Checklist of non-vascular and vascular plants of Slovakia. Bratislava: Veda, vydavatel'stvo SAV.

Májeková, M. \& Vykoukalová I. (2010). Communities of hard riparian forests of the south - eastern part of the territory of Bratislava (in Slovak). Bulletin Slovenskej Botanickej Spoločnosti, 32, 239-251.

Medvecká, J., Kliment, J., Májeková, J., Halada, L., Zaliberová, M., Gojdičová, E., Feráková, V. \& Jarolímek I. (2012). Inventory of the alien flora of Slovakia. Preslia, 84, 257-309.

MoE SR (2003). Decree of the Ministry of the Environment of the Slovak Republic no. 24/2003 Coll., Amending the Decree of the Ministry of the Environment of the Slovak Republic no. 24/2003 Coll., which implements Act no. 543/2002 Coll. on Nature and Landscape Protection, Volume 13/2003, as amended. https://www.zakonypreludi.sk/ zz/2003-4. 
Moravec, J., Blažeková, D., Hejný, S., Husová, M., Jeník, J., Kolbek, J., Krahulec, F., Krečmer, V., Kropáč, Z., Neuhäusl, R., Neuhäuslová-Novotná Z., Rybníček, K., Rybníčková, E., Samek, V. \& Štěpán J. (1994). Phytocoenology (Vegetation Science) (in Czech). Praha: Academia.

Nicolescu, V., Rédei, K., Mason, W.L., Vor, T., Pöetzelsberger, E., Bastien, J.-Ch., Brus, R., Benčat, T., Dodan, M., Cvjetkovic, B., Andrašev, V., La-Porta, N., Lavnyy, V., Mandžukovski, D., Petkova, K., Roženbergar D., Wąsik, R., Mohren, G.M.J., Monteverdi, M.C., Musch, B., Klisz, M. Perić, S., Ljiljana Keça, L., Bartlett, D., Hernea, C. \& Pástor M. (2020) Ecology, growth and management of black locust (Robinia pseudoacacia L.), a non-native species integrated into European forests. J. For Res., 31, 1081-1101. DOI: 10.1007/s11676-020-01116-8.

Pauková, Ž. (2013). Invasive plant species in the three microregions of Nitra region, south-west Slovakia. Ekológia (Bratislava), 32(2), 262-266. DOI: 10.2478/eko-2013-0022.

Paunović, M., Csányi, B., Simonović, P. \& Zorić K. (2015). Invasive alien species in the Danube. In I. Liska (Ed.), The Danube River Basin (pp. 389-409) Berlin-Heidelberg: Springer-Verlag. DOI: 10.1007/978-3-662-47739-7.

Perzanowska, J., Korzeniak, J. \& Chmura D. (2019). Alien species as a potential threat for Natura 2000 habitats: a national survey. PeerJ, 7, e8032. DOI: $10.7717 /$ peerj.8032.

QGIS.org. (2015). QGIS Geographic Information System. Open Source Geospatial Foundation. https://qgis.org/en/site/.

Regulation (EU) No 1143/2014 of the European Parliament and of the Council of 22 October 2014 on the prevention and management of the introduction and spread of invasive alien species. https://eur-lex.europa.eu/ legal-content/sk/TXT/?uri= CELEX: 32014R1143.

Rejmánek, M., Richardson, D.M. \& Pyšek P. (2013). Plant invasions and invasibility of plant communities. In E. van der Maarel \& J. Franklin (Eds.), Vegetation ecology (pp. 387-424). John Wiley and Sons. DOI 10.1002/9781118452592.ch13.

Richardson, D.M. \& Rejmánek M. (2011). Trees and shrubs as invasive alien species - a global review. Divers. Distrib., 17, 788-809. DOI: 10.1111/j.1472-4642.2011.00782.x.

Sheldon, A.L. (1969). Equitability indices: Dependence on the species count. Ecology, 50, 466-467. DOI: 10.2307/1933900.

SHMÚ (2019). Water management balance of surface water in 2018 (in Slovak). Bratislava: SHMÚ. http://www.shmu.sk/File/Hydrologia/ Vodohospodarska bilancia/VHBkvantitaPV/VHB\%202018_ skr\%C3\%A1ten\%C3\%A1\%20verzia.pdf.

Simpson, E.H. (1949). Measurement of diversity. Nature, 163, 688. DOI: $10.1038 / 163688 \mathrm{a} 0$.

Spellerberg, I.F. (2008). Shannon-Wiener Index. In S.E. Jorgensen \& B. Fath (Eds.), Encyclopedia of ecology (pp. 3249-3252). Academic Press. DOI: 10.1016/b978-008045405-4.00132-4
StatSoft, Inc. (2004). STATISTICA Cz. verze 7. http://www.StatSoft.Cz.

Špulerová, J., Dobrovodská, M., Šatalová, B. \& Kanka R. (2017). Small woodlands and trees in traditional agricultural landscapes of Slovakia. Journal of Landscape Ecology, 10, 63-77. DOI: 10.1515/jlecol-2017-0014.

Štajerová, K., Šmilauer, P., Brůna, J. \& Pyšek P. (2017). Distribution of invasive plants in urban environment is strongly spatially structured. Landsc. Ecol., 32, 681-692. DOI: 10.1007/s10980-016-0480-9.

Ter Braak, C.J.F. \& Šmilauer P. (2018). Canoco reference manual and user's guide: software for ordination, version 5.10. Ithaca: Microcomputer Power.

Tichý, L. (2002). JUICE, software for vegetation classification. J. Veg. Sci., 13, 451-453. DOI: 10.1111/j.1654-1103.2002.tb02069.x.

Tichý, L. \& Jason H. (2006). JUICE program for management, analysis and classification of ecological data. Program manual, Vegetation Science Group. Brno: Masaryk Univerzity. https://www.sci.muni.cz/botany/ juice/JUICEman_all.pdf.

Tomlain, J. (2002). Average annual values of the climate irrigation indicator (in Slovak). In T. Hrnčiarová (Ed.) et al., Atlas krajiny Slovenskej republiky. Bratislava: MŽP SR, Banská Štiavnica: SAŽP, ESPRIT.

Uherčíková, E. (2001). Invasive plant species in floodplain forests on the Danube (in Slovak). Životné Prostredie, 35, 78-82.

Vadas, E. (1914). Die Monographie der Robinie mit besonder Rücksicht auf Ihre forstwirtschafliche Bedeutung. Selmecbánya.

Vannote, R. R., Minshall, G.W., Cummins, K.W., Sedell, J.R. \& Cushing C.E. (1980). The river continuum concept. Can. J. Fish. Aquat. Sci., 37, 130-137. DOI: 10.1139/f80-017.

Vilà, M. \& Ibáñez I. (2011). Plant invasions in the landscape. Landsc. Ecol., 26, 461-472. DOI: 10.1007/s10980-011-9585-3

Vítková, M., Müllerová, J., Sádlo, J., Pergl, J. \& Pyšek P. (2017). Black locust (Robinia pseudoacacia) beloved and despised: a story of an invasive tree in Central Europe. For. Ecol. Manag., 384, 287-302. DOI: 10.1016/j. foreco.2016.10.057.

Vološčuk, I. (2002). Invasive species of dendroflora in protected areas (in Slovak). Acta Facultatis Ecologiae, 9, 55-60.

Zelený, D. (2012). Notes on the use of average Ellenberg indication values in the analysis of vegetation data (in Czech). Zprávy České Botanické Společnosti, 47, 159-178.

Zelený, D. \& Schaffers A. (2012). Too good to be true: pitfalls of using mean Ellenberg indicator values in vegetation analyses. J. Veg. Sci., 23, 419431. DOI: $10.1111 /$ j.1654-1103.2011.01366.x. 